\title{
Contaact of Sale According to Kosovo Legislation
}

\section{Abstract:}

The contract of sale represents one of the most important contracts on internal and external circulation of goods. This contract is considered one of the oldest and it has the same purpose in all the countries worldwide. With this contract, the seller is obliged to deliver the goods he sells to the buyer, in order for him to gain the right of ownership, whereas the buyer is obliged to pay the price as per the contract.

\section{Keywords:}

validity conditions, resolution and consequences of resolution, etc. In some occasions, the contracts are subjects of different conflicts which reach the only solution through courts. Given the fact that there are different types of the contracts of sale, it is important that we make efforts in order to study them, difficulties we encounter with regards to the circulation of goods and money.

Contract on sale; seller; buyer; circulation; goods; characteristics; solution

\section{Author's data:}

1 Professor at the Law Faculty - AaB College, Prishtine - Kosove (skender.gojani@uiversitetiaab.com)

2 Professor at the Law Faculty - AAB College, Prishtine - Kosove (granit.curri@uiversitetiaab.com)

International Journal - VALLIS AUREA • Volume 7 • Number 1 • Croatia, June 2021 


\section{Introduction}

The contract is the main and the most important source of liability relationships. A contract is an agreement between two or more persons, which intends to create, modify or terminate a legal obligational relationship.

Contracting obligation may consist of giving, action, inaction or patience. obligation must be possible, permissible and definite.

\section{Historical aspect of the contract}

\section{of sale}

The influence of the Roman Law in the modern world has been tremendous as it forms the historical basis of many legal systems worldwide. The Roman Law did not consider every agreement between the parties a contract. Only the agreements associated with the right to sue were considered contracts.

According to Roman Law when the creditor and the debtor agreed upon the sale of a particular item, new rights and obligations between the creditor and debtor arise thus there will be new rights for the creditor and debtor who may ask for actions to be taken thus obligations for both: the creditor and the debtor arise [1, p. 305]. Adjustment of wills of the subject matter of the contract was called conventio [2, pp. 343-349]. The contract of sale (emptio venditio), is a consesual, bilateral contract that arises by simple agreement between the seller and the buyer so that the seller delivers the goods in unimpeded possession to the buyer and the buyer pays the price set to the seller. The sale was a bilateral or mutual contract which means that rights and obligations arise for both the seller and the buyer [2, pp. 343-349]. This further suggests that, according to the Roman Law on signing a contract of sale, there should first of all be an agreement between the seller and the buyer for the sale of the particular item which is valid as soon as the contract is signed and some of the following conditions must be met: adjustment of the will of the parties, legal capacity and action, the form of the contract and the object (particular item) for which the parties create rights and obligations arising from the contract of sale according to which the creditor asks the debtor to buy and take particular item under his/her possession which, in fact, is the object of the contract, whereas the debtor asks from the creditor to pay the price for the item sold.

\section{Understanding the contract of}

\section{sale}

The contract is the main and the most important source of liability relationships. A contract is an agreement between two or more persons, which intends to establish, change or terminate a legal obligational relationship. Law on obligational Relationship has not defined the notion of the contract but in the Article 26 it states that the contract is concluded when the parties have agreed on the essential elements $[3, p$. 17]. The contract of sale exists when the seller takes on the responsibility of delivering the item sold to the buyer so that the latter gains the right of ownership, whereas the buyer takes on the 
responsibility to pay the price agreed upon. [4, pp. 131-140]

\section{Characteristics of the contract of}

\section{sale}

The contract of sale is informal the legal form is defined for the contract of sale of real estate] namely, obligatory for both the parties, with charge, causes, cummutation, with liabilities on immediate execution or duration and specific content as per the agreement or access. [5, p. 366]

\section{Elements of the contract of sale}

Elements of contract of sale are: goods and price. The sale in the contract of sale is valid even when the price has not been set because the law provides for the manner of setting the price. [6, p. article 445]

Goods are a fundamental element of the contract. In many instances, in the literature the term item is used. In our legislation, the contract of sale can have as subject: electricity, gas, solar energy, etc. The following are considered items: movable items, immovable property and non-physical rights $[7, \mathrm{p}$. article 81. According to the provision of the article 34 para 2 of LOR, it can be any item and right in legal circulation, except from the item which, according to law, is out of circulation. The right may be an element of this contract if it is the transferable property right (the right to property, usufruct, copyright, etc.]. [8, p. 545]

\section{Price}

Price is the monetary equivalence that the seller sells to the buyer. Price is to be expressed in money [4, pp. 131-140]. Price is the amount of money that the buyer is obliged to pay to the seller in return for the item or the right that he has bought from the seller $[8, p$. 545]. If the price is not set in the contract of sale, and the contract does not contain sufficient data that could set the price, the contract has no legal effect [6, p. article 445].

When the price is contracted higher than that for the certain type of items determined by the competent body, the buyer owes only the amount of the set price: if the contracted price has been paid, the buyer has the right to request the returrn for the difference [6, p. article 446].

As a rule, the contract price is decisive or the contract contains the sufficient data with the help of which the price (fixed price) can be set. $[5, \mathrm{p}$. 366]

\section{Obligations of the parties in the}

\section{contract of sale}

\section{Obligations of the seller}

In the contract of sale, the seller has the following basic obligations: a) to send the sold goods to the buyer, b) transfer to him the right to ownership; c] protect the buyer from legal-material deficiencies, as a defect of the goods.

In civil law, for the realization of the property right, sending is distinguished from the delivery (tradition]. With the conclusion of the contract for 
sale, in civil law, an obligatory relationship is created between the seller and the buyer which is the basis (title) for the realization of the property right, for things or any other right. In economic law, the delivery of goods has, in the first place, a legal-obligatory character, while in civil law it has a legal character. The buyer, to whom the goods have been delivered, as a rule exercises the property right over it. However, it may happen that the goods have been sent and not delivered to the buyer, thus not enabling him to acquire the right of ownership. [4, pp. 131-140]

\section{Manner of delivery of goods}

Delivery of goods is characterized by its physical delivery owned by the buyer accompanied by the symbolic delivery of documentation to the buyer based on which the buyer can possess the goods as well as the delivery of a part or in various ways of marking things which means their delivery, for example with the delivery of the warehouse keys, the delivery of the goods documentation, the warehouse documentation, the loading list, the accompanying documentation or the fictious delivery, when the delivery is done with the declaration of the will of the contracting parties, which changes the basis for holding the goods [5, p. 366].

Delivery of goods can be done first hand (tradition brevimanu], if the buyer keeps the goods, for example: as a deposit or tenant of the business space where he buys the goods, eg as a deposit or tenant of the business space where he buys the goods and acquires the right of ownership at the moment of concluding the contract [4, pp. 131-140].
Acquisition of ownership of a movable item requires a valid legal work between the transferor and the acquirer of the property as well as the delivery of the item to the acquirer of the ownership. [7, p. article 21]

While the acquisition of ownership in real estate requires a valid legal work between the alienator and the winner as a legal basis and the registration of the change of ownership in the Register of Immovable Property Rights. [7, p. article 36].

\section{Place of delivery of goods}

The seller has the duty to deliver the item to the buyer at the time and place provided by the contract. The seller has in principle fulfilled the obligation of delivery to the buyer, when he (the seller) delivers the item to the buyer or delivers the document with which the item can be obtained. [6, p. article 450].

Unless something else is contracted, or something other than the nature of the work itself, the seller has a duty to deliver the item to the buyer in good condition along with its accessory parts. Fruits and other benefits from the item belong to the buyer from the moment when the seller had the duty to deliver it to him. [6, p. article 458].

The chosen place where the delivery of goods should take place is a place determined by contract. The seller, who has the obligation to deliver the goods to the buyer, must, in a regular manner and under normal conditions, enter into a contract for the transport of the goods to the designated place and deliver it to the buyer at the time provided by the contract. [4, pp. 131-140] 
Liability for defects

1. The seller is responsible for the material defects of the item, which he had at the moment of passing the risk to the buyer, regardless of whether the seller was aware or not of the defects of the item.

2. The seller is also liable for those material defects, which appear after the transfer of risk to the buyer, if they are a consequence of the causes which have existed before.

3. Insignificant material defect is not taken into account. [6, p. article 461].

\section{Visible and invisible defects of the goods}

Visible defects of the goods are those defects which, the caring person with average knowledge and experience of the person from that profession, as a buyer, has been able to notice with an ordinary look of the goods. The visible defects in this way are determined objectively according to the premeditated average buyer and not based on the care of the concrete average buyer. [9, p. 140] The seller is not liable for defects which appear after six (6) months have passed from the delivery of the item, unless a longer term is stipulated in the contract. [6, p. article 465]

The rights, authorizations and obligations of the buyer

The buyer who has notified the seller in a timely and orderly manner of the defect may: 1 . Ask the seller to eliminate the defect, or to deliver the other item without defects (fulfillment of the contract), 2. Request a price reduction, 3. Declare the termination of the contract. [6, p. article 471]
The buyer, who due to the defects of the goods has suffered damage (regardless of whether or not he has requested fulfillment of obligations from the contract or price reduction and breach of contract] is entitled to compensation for damage. [4, pp. 131140]

If the buyer does not obtain the required fulfillment of the contract within a reasonable time, he retains the right to terminate the contract or reduce the price. [6, p. article 472]

Guarantee for the proper functioning of the item sold

When the seller of a car, engine, apparatus, or other items such as these belongings to the socalled "technical goods", has submitted to the buyer a guarantee sheet with which the manufacturer guarantees the proper operation of the item for a certain period of time calculating from its delivery, the buyer may, if the item does not function properly, request from both the seller and the manufacturer that the item be repaired within a reasonable time or, if they do not do so, or instead replace it, hand over the item which functions properly. [6, p. article 484]

\section{Liability for legal deficiencies}

The seller is liable if there is a third party right in the sold item which excludes, reduces or restricts the buyer's right, and the buyer has not been notified of its existence, nor has he given his consent to take the item, charged with this right. If in public registers any rights have been registered or any of the third parties, which in 
reality does not exist, the seller is obliged at his own expense to deregister that right. [10]

\section{Obligations of the buyer}

The buyer is obliged to pay the price at the time and place specified in the contract. If the price does not have to be paid at the time of delivery, payment is made at the place of residence, respectively at the seller's main office. [6, p. article 499]

Interest in case of sale on credit-If the item sold on credit gives usufruct or other benefits the buyer debits interest from the moment the item is delivered to him regardless of whether the obligation to pay the price has arisen or not. $[6, p$. article 500]

The buyer who does not want to accept the item that was sent to him at the place of destination and that was left there at his disposal, has the duty to take over on behalf of the seller, if he is not present at the place of destination, nor that there is someone who had to take over the thing for him, provided that this is possible without paying the price and without great complications or excessive expenses. [6, p. article 504]

\section{Joint obligations of the contracting parties}

One party may suspend the fulfillment of its obligations if after the conclusion of the contract, it becomes clear that the other party will not fulfill the essential part of its obligations, as a result: 1 . of a severe impossibility in his ability to accomplish it or in his working ability. 2. of the manner in which it is prepared to start or continue the implementation of the contract. [11, p. article 740]

\section{Termination of contract of sale by the seller}

If the buyer without any reasonable cause refuses to take the item, the delivery of which has been offered to him in a contracted or usual manner and on time the seller may declare that he terminates the contract, if there is a reasonable reason to doubt that the buyer will not pay the price.

\section{Termination of the contract of} sale by the buyer

The buyer can terminate the contract only if he has previously given the seller a reasonable additional deadline for fulfilling the contract. The buyer can terminate the contract even without leaving the new additional term if the seller after notifying the defects has informed him that he will not fulfill the contract or if from the circumstances of the concrete case it is clear that the seller will not be able to fulfill the contract even in the additional term. [6, p. article 473]

\section{Consequences of termination of the contract of sale}

When the sale is terminated due to breach of contract by one of the contracting parties the other party is entitled to compensation for the damage, 
he suffers for this according to the general rules for compensation for the damage caused by breach of contact. [6, p. article 506]

When the sale is terminated due to breach of contract by one of the contracting parties, while the item had a current price, the other party may claim the difference between the contract price and the current price on the day of termination of the contract in the market of the country where the work is done. [6, p. article 507]

\section{Types of contracts of sale}

\section{Sale with the right of pre-purchase}

The contractual provision on the right of prepurchase obliges the buyer to inform the seller on the sale of the item he intends to make to the designated person, as well as on the terms of this sale and to offer him to buy the item at the same price. [6, p. article 510]

The right of pre-purchase can be created through law or through contract. The contractual right of pre-purchase is created through an agreement between the owner of the immovable property and the person who has the right of pre-purchase. The right of pre-purchase becomes valid against third parties, if it is registered in the Register of Immovable Property Rights. [7, p. article 44]

The seller has the duty to notify the buyer safely of his decision to use the right of pre-purchase within a period of thirty (30) days counting from the day when the seller has notified the seller that he intends to make the sale to the third person.

Simultaneously with the statement that he buys the item, the seller has the duty to pay the notified price to the third person or to deposit it in court. [6, p. article 511]

\section{Purchase on test}

When it is contracted for the buyer to take the item on condition that he tests it and that it responds to his wish, the buyer has the duty to inform the seller within the term specified in the contract or according to the docs whether he sticks to the contract and if there is not such a thing then within the reasonable time which the seller would have assigned to him, otherwise it is considered that he has given up the contract.

If the item has been delivered to the buyer to prove it by the deadline and he does not return it by deadline or does not declare to the seller that he withdraws from the contract, it is considered that he has remained close to the contact. [6, p. article 517]

\section{Sale by model}

In the case of sale by sample or model, in contracts between entrepreneurs if the item which the seller has delivered to the buyer is not the same as the sample or model, the seller is liable under the provisions for the seller's liability for material defects of the item, while in other cases, the seller is liable under the provisions on liability for nonfulfillment of the obligation.

\section{Sale with specification}

If the contract reserves the right for the buver to determine later the form, measure or any other characteristic of the item, and the buyer does not perform this specification by the contracted date, 
or until a reasonable time has elapsed, calculating at the request of the seller to do so, the seller may declare that he terminates the contract or make the specification according to what he is aware of with regards to the needs of the buyer.

If the buyer does not take advantage of this opportunity, the specification made by the seller remains mandatory. [6, p. article 522]

\section{Conditional sale}

The seller of a certain movable item may, through a special provision in the contract, retain the right of ownership over the item given to the buyer until the buyer pays the sale price. The preservation of the property right has effect for the creditor of the buyer only if the signing of the contract containing the provision of the preservation of the property right is notarized before the bankruptcy of the buyer or the attachment to the movable property. [6, p. article 523]

\section{Installment sale}

Under the installment contract, the seller is obliged to deliver to the buyer a special moveable item before the purchase price is paid in full, and the buyer is obliged to pay in installments within a certain time period.

\section{Sale through letters of credit}

If there is an agreement that the payment be made by letter of credit, the buyer is obliged to ensure at his own expense within a reasonable time that the first bank installment opens a letter of credit that is in accordance with the contract of sale.
The letter of credit must be valid for a sufficient time after the seller's obligation has been fulfilled so that the seller can collect and submit the documents to the bank. [6, p. article 530]

\section{Order of sale}

The contract of sale order obliges the recipient of the order to sell the certain movable item given to him by the ordering party, at a certain price in the specified term or to return it to the ordering party within that term. The sales order cannot be revoked [6, p. article 531]

The item delivered to the order recipient remains in the ownership of the ordering party and he bears the risk of its accidental destruction or damage but he cannot possess it until it is returned to him. [6, p. article 532]

\section{Conclusion}

The contract of sale has a great importance not only within our country but also in different countries of the world as it serves for the internal and external circulation of goods.

International contracts of sale are defined by the United Nations Convention on Contracts for the International Sale of Goods, otherwise known as the Vienna Convention on Sales. When looking to buy a property, it is very important to know what the contract of sale is, what its effect and its role in this agreement is, we should also be aware of the legal procedures.

The contract of sale contains the following characteristics: It is legal- that is, it is legally enforceable, it is a bilateral contract - it sets the 
agreement between a seller to sell and a buyer to buy at an agreed price, it is communicative - given the fact that benefits are determined and are certain when the contract is executed, it is a formal and consensual contract -the contract is a voluntary agreement between the parties and those parties must be legally competent to make a formal agreement. Before signing the contract, we must make sure to read the document carefully and ask questions to the other party to clarify the points of the contract. We must be careful not to make mistakes in names, addresses, as well as in the amount of monev and consult each other about legal terms and other procedures.

\section{References}

[1] I. Puhan, Roman Law, Pristina, 1988, p. 305.

[2] A. Mandro, Roman Law, Tirana, 2006, pp. 343-349.

[3] N. Dauti, Internationla Law - Praktikum, Pristina, 2003, p. 17.

[4] S. Gojani and G. Curri, Contracting Law, Pristina, 2020, pp. 131-140.

[5] A. Krasniqi, Business Law, Peja, 2014, p. 366 .

[6] A. o. t. R. O. Kosovo, Law no. 04/L-077 on obligation relationships, Pristina: Official Gazette of the Repulic of Kosova, 2012.

[7] A. o. t. R. 0. Kosovo, Law no. 03/L-154 on property and other rights, Pristina: Official Gazette of the Republic of Kosova, 2009.

[8] Handbook for Preparation of the Bar Exam, Prishtinë: Ministry of Justice, 2015, p. 545.

[9] N. Dauti, Contract, Pristina, 2012, p. 140.
[10] [0nline]. Available: https://md.rksgov.net/desk/inc/media/A1CCB78F-9020-4105826E-14D67A90F369.pdf. [Accessed 15 June 2021]. [11] [Online]. Available: https://WwW.infocip.org/al/?p=6300. [Accessed 15 June 2021]. 